\title{
From Cost-Benefit to Institutional Analysis in The Economics of the Environment
}

\author{
Lenka Slavikova
}

ABSTRACT

Economics of the environment as an applied field of economics was established during the 1960s. At the time of its foundation, neoclassical environmental economics represented the mainstream view regarding the explanation of the causes of environmental problems and their solutions. Since then, however, two other competing approaches - the free market and institutional ecological economics - have evolved. These two new approaches present different analytical focuses as they stress the role of institutions (property rights and/or management regimes) in environmental protection. As a result, environmental research based on cost-benefit analysis was substituted by the application of various forms of institutional (often qualitative) analyses. The goal of the paper is to justify the importance of this methodological shift that is sometimes minimized by mainstream economists. The research focus of competing approaches and their methods are mapped through comparative analysis, and the theoretical description is connected with the practical examples of the EU environmental policy.

KEY WORDS: $\quad$ institutional analysis; environmental economics; qualitative research; interdisciplinarity

JEL Classification: Q50, B25

1 University of Economics in Prague, Czech Republic

\section{Introduction}

Economics of the environment is a relatively young field of applied economics. During the 50 years of its existence, it has gone through a dynamic process characterized by the evolution of alternatives to mainstream neoclassical environmental economics. The mainstream view identifies market failures (such as externalities and public goods) as key causes of the environmental degradation and proposes different types of government regulations as solutions to this degradation. The monetary valuation of natural goods or environmental damages (as part of cost-benefit calculations) represents the main tool of the analysis. The

Correspondence concerning this article should be addressed to: Lenka Slavikova, University of Economics in Prague - IEEP, Institute for Economic and Environmental Policy, W. Churchill Square 4, Prague 3 13061, Czech Republic, e-mail: slavikova@ieep.cz subsequent evolution of competing thoughts regarding this mainstream view has been proportionate to the growing importance of environmental problems as reflected by society since the mid- $20^{\text {th }}$ century.

Publications describing the ideological and methodological progress of different schools of thought within the economics of the environment are rather scarce. Kula (1998) addresses fragments of different approaches from medieval philosophy, via neoclassical economics to current thoughts, inspired by the sustainability movement (including various ethical and religious thoughts). Brief historical excursions are contained in environmental and ecological economics textbooks (such as Common \& Stagl, 2005; Pearce \& Turner, 1990), while overviews of the theoretical development within the economics of the environment are contained in proceedings of key academic papers (Hoel, 2004; Oates, 1994). The absence of a systematic overview of the competing approaches 
Table 1. Overview of positions of different theoretical schools of thought

\section{Causes of environmental problems}

Neoclassical environmental economics

Market failures

Free market approaches

Government failures

Misfits between institutions and

Institutional ecological economics ecosystems (wrong institutions)
Solutions

Pigouvian taxation

Public provision of goods and services

Introduction of individual property

rights

Institutional changes accenting

environmental governance principles (including a comparison of their assumptions, methods and policy recommendations) complicates orientation in statements, opinions and terminology (more in Slavíková et al., 2010). Accordingly, it is not easy to identify borders among the competing schools of thought, to detect new trends and, especially, to build a dialog among economists working in this field.

Still, a growing body of literature over the past two decades has made the shift from pure cost-benefit calculations to more complex institutional analyses clear (Anderson \& Snyder, 1997; Young, 2002). Methods developed for the investigation of environmental problems aim to capture a broader spectrum of social features that influence human behavior (such as political and cultural aspects) and to integrate research techniques from other scientific disciplines (Poteete et al., 2010).

The goal of the paper is to justify the importance of this methodological shift regarding the solutions to the environmental problem. Particularly, the following two questions will be addressed: What are the existing theoretical approaches within the economics of the environment? What are the new developing (often qualitative) methods of analysis and how do they help to solve the environmental problems? The comparative and descriptive methods based on extensive literature reviews are applied to map existing phenomena. Within the paper, the expression "economics of the environment" (or, alternatively, "economics of environmental protection") is used as the general term for the application of different economic thoughts to the problem of environmental protection. The paper focuses on human behavior related to use vs. protection of natural resources, including conflict resolution under various types of institutional arrangements.

The paper is comprised of three chapters. Chapter 1 addresses the classification of theoretical approaches within the economics of the environment. Chapter 2 describes the essence of the methodological shift from the cost-benefit to the institutional analysis. Finally, chapter 3 justifies the need for institutional analysis and presents some EU environmental policy evidence to support the application of heterogeneous research methods.

\section{Fragmentation of the field - who, when and why?}

Based on the investigation presented in Jílková and Slavíková (2009) and Slavíková et al. (2010), three main theoretical approaches within the economics of the environment have been institutionalized, thus offering different views on environmental problems and their possible solutions. These are as follows:

- mainstream neoclassical environmental economics,

- institutional ecological economics and

- free market approaches to environmental protection.

These three different views are summarized in table 1. Additionally, few other minor groups or sub-groups exist, such as direct followers of Ronald Coase (i.e., applications of new institutional economics on the problem of environmental protection), natural resource economists, among others. Within the paper, their ideas are incorporated into the relevant dominating approaches. Furthermore, the social research that is not grounded in economics has not been addressed (thus excluding fields 
of environmental ethics, sociology, etc.). Minor fields of specific interdisciplinary research, e.g., economics and psychology (see Frey \& Stutzer, 2008) or environmental law and economics (see Germani, 2004), have also, to a large extent, been excluded.

From table 1, it is apparent that two competing approaches to the mainstream have evolved over the past two or three decades. Free market approaches refer to liberal economic theories of the Austrian schools of thought (especially economist Murray Rothbard) and, in part, the public choice school of James Buchanan. These theories stress government failure problems and emphasize the role of individual motivations to protect the self, and thay accordingly call for the introduction and protection of private ownership (see Anderson \& Leal, 2001; Cordato, 2004). On the other hand, institutional ecological economics, which is a continuation of the traditional (or normative) ecological economics represented by Herman Daly and Robert Costanza, focuses on the study of mutual interactions among social and ecological systems and aims to design the proper institutions to solve the problem regarding protection vs. the use of natural resources in the long-term (Paavola, 2007; Vatn, 2005; Young, 2002). This perspective also strongly refers to the empirical research of the American political scientist Elinor Ostrom (see Ostrom, 2006; 2008).

Both of the aforementioned alternatives to the mainstream neoclassical approach agree that "institutions matter", and they both stress the existence of government failures, which were neglected in the neoclassical approach. However, they significantly differ in their key methodological issues, such as the understanding of human rationality, methodological individualism vs. collectivism, the role of ethics in socioeconomic research, etc. (see Slavíková et al., 2010).

Nevertheless, it is clear that institutions became to be viewed as influential factors of resource allocation, and the changing of institutions has had significant distributional impacts as institutional structures provide individuals with incentives to either conserve or deplete scarce (natural) resources (Anderson \& Leal, 2001; Ostrom, 2005; Paavola, 2007). This perspective is in strong contrast with the neoclassical approach that views institutions as neutral regarding resource allocation (institutions are an exogenous variable in neoclassical models) due to assumptions of zero transaction and information costs (Furubotn and Richter, 2005). Which institutions are the right ones, however, is the subject of dispute, and accordingly, the impacts of private, collective and state ownerships in combination with different management practices have been the subject of various studies (Stroup, 2000; Vatn, 2005).

With respect to the institutional perspective, it is worth noting that two theoretical schools - the traditional and new institutional economics - are viable inspirations for different scientists from both alternative groups. From the traditional school, the institutional ecological economists adopted the notion of the social pre-determination of individual human preferences (as explained, e.g., by Veblen, 1899) - see, e.g., the work of Arild Vatn (2005). This belief led them to question the methodology of neoclassical environmental economics, especially with respect to its focus on methodological individualism and perfect rationality of consumers. From new institutional economics, the transaction cost theory and the concept of bounded rationality (Williamson, 1981) became the main milestones reflected in different contexts. Institutions, defined by both internal and external social rules of the game (see, e.g., North, 2005 among others) are analyzed on a theoretical (Cordato, 2004) as well as an empirical basis (Young, 2002).

Fragments of consensual results among free-market and institutional ecological economists were revealed in empirical case studies by Elinor Ostrom and Terry Anderson. Both authors analyzed spontaneously evolved property regimes of local irrigation systems in the USA (Anderson and Snyder, 1997), Spain and the Philippines (Ostrom, 2006). In the American case, the authors described the gradual evolution of water markets based on individual water rights. In the latter case, the social cooperation in running irrigation systems proved the viability of communal ownership. However, due to the bottom-up evolution of successful institutional arrangements, the authors do not ascribe the normative value to any type of water problem solution. According to Ostrom et al. (1999), private property may be established, especially when the exclusion of others is inexpensive and when the potential owner withdraws only a small portion of the resource in use. On the other hand, free-market economist Edwin Dolan (2006) states that if there are not enough resources left in the common-pool, the further ap- 
propriation by any individual can proceed only with the consent of other users (i.e., based on social agreement). Under specific conditions, both communal and private ownership can represent the efficient alternative for the resource users providing they are free to decide on the appropriate institutional arrangement (Šíma, 2004). This partial consensus is apparent despite the fact that different research methods (empirically based vs. deductive) are used to support particular statements.

\section{The methodological shift}

The identification of two novel approaches within the economics of the environment give rise to the change in the investigation focus at the scene. Instead of calculating the optimal tax or the proper monetary value of natural resources in general, a growing group of researchers began to study natural resource property regimes with the aim to design institutional reforms. For this purpose, different methods and analytical techniques are introduced. In this context, the methodological discussions include the following two key issues, which will be addressed herein:

a) the position of qualitative vs. quantitative methods, b) the rationale for interdisciplinary methods.

\subsection{Words and/or numbers?}

Current mainstream microeconomics (from which the neoclassical environmental economics is directly derived) is, to a large extent, quantitatively oriented. This approach is illustrated by Jilková et al. (2010) as they investigate the willingness to pay for the infrastructural improvement of natural places of interest through the contingent valuation method. According to this method, interviewed people express their preference to pay for a certain public good, a good from which potential benefits are derived (and can be compared with costs of the provision). Thousands of different evaluation studies based on different valuation techniques have been published - for more, see, e.g., Journal of Environmental Economics and Management or Environmental and Resource Economics. Both journals represent the current focus of neoclassical environmental economics.

However, a growing number of social scientists propose the combination of quantitative and qualitative methods with respect to the subject of analysis, where - and this must be emphasized - the methods are only
MEANS and not the final GOAL of the research effort. A high level of abstraction in formal models challenges the practical applicability of these methods. On the other hand, the external validity of the qualitative analyses of case studies may be very low. The crucial point is to combine advantages of both types of methods whenever necessary (Poteete et al., 2010). Accordingly, the qualitative research is no longer in an inferior position (Hendl, 2005). Even an economic analysis can be based on interviews and desk-studies (Kornai, 2008). Furthermore, as emphasized by Poteete et al. (2010, p. 4), "No method is immune to poor applications."

Within the economics of the environment, the study of property regimes (including different types of ownership and use rights) calls for methodological flexibility. For example, when analyzing human action related to common-pool resources, the data on particular observations are scarce and are thus difficult to find and difficult to compare. The case study approach, therefore, is a possible solution (Poteete et al., 2010). To support the external validity of conclusions, two different strategies are implemented by promoters of qualitative methods. The first strategy relies on the collection of numerous case studies over time and the development of the common comparative framework necessary to analyze the studies (see the description of IAD Framework in Poteete et al., 2010). Empirically based results of a large number of case studies may verify or confute the given hypotheses. Or, as emphasized by Ostrom et al. (1999), they may even challenge conclusions deducted from the economic theory. This procedure is pursued by institutional ecological economists. The second strategy attempts to ground the whole research deeper into economic theory, so the empirical findings, to a large extent, support the theoretical conclusions. A small number of observations is sufficient for the illustration of a problem and its solution (see, e.g., the analytic narrative method in Bates et al., 2000). This approach is characteristic of free-market economists.

The common feature of the presented analytical methods is the consistent description of the institutional background. Accordingly, any description should include a description of the actors and an understanding of their relationships, motivations, cultural and social norms, etc. The evaluation of particular situations is derived from the chosen theory, and the key moment for a researcher is the explanation of 
(with the proper theoretical reference) what is considered to be the effective or optimal solution and why.

A good example of the qualitatively oriented institutional research is embodied in Ostrom (2006). Based on the numerous case studies of local property regimes of common-pool resources, Ostrom derived general principles of the successful governance for specified sub-groups of resources. These principles strongly refer to the self-governance undertaken directly by resource users. Later, Ostrom and her team developed the qualitative tool known as the Institutional Analysis and Development Framework (IAD) to enable a better comparison of heterogeneous research within this field (see, e.g., Ostrom, 2005).

\subsection{Interdisciplinarity}

Interdisciplinary research within the economics of the environment mainly aims at connecting the two groups of scientists to utilize the advantages of both the exact natural sciences and the socially conditioned outcomes of the social sciences. As emphasized by Berkes and Folke (1998), we must make use of both the expert knowledge of ecosystem functioning and the institutional, economic and political factors conditioning the responses of the social systems. The relationship between social and natural sciences must, therefore, be understood as equipollent, just as social (human) and ecological (biophysical) subsystems are interconnected and influenced by their mutual interactions. Adaptation of human society to the changing environment cannot be achieved by relying solely on findings of natural sciences, because any proposed measures will not be accepted without the majority of society reflecting on those findings. Conversely, the social sciences by themselves are not able to generate expert know-how for understanding the impacts of human society on ecosystems.

In addition to the effort that aims to interconnect the research agenda of the social and natural sciences, the interdisciplinarity may also include the cooperation among different social science disciplines - the most frequent being economics and political sciences, economics and law or economics and sociology. The successful example of the first involves the incorporation of the Elinor Ostrom research into institutional ecological economics, even though her empirically grounded findings on the robustness of the commu- nal ownership have been transferred into normative recommendations (see, e.g., Vatn, 2005). Further, different authors offer their original contribution, such as Siegers (1992, p. 544), who states that "the general framework of the rational choice theory can be used to combine the strong points of economics and sociology" or Germani (2004), who applies the general framework of the law and economics theory to environmental issues. However, as emphasized by Huutoniemi et al. (2010), developing interdisciplinary approaches is a time-consuming process, wherein achieving methodological interdisciplinarity is a significant problem.

The need for interdisciplinarity, however, is promoted mainly by institutional ecological economists (see Beder, 2011). Neoclassicists together with free-market economists argue that economics by itself is capable of giving necessary answers on how to address natural resources. Thus, the expert knowledge of natural scientists is relevant only when reflected by individuals and/or elected representatives of society.

Differences between the discussed methods - the cost-benefit and institutional analyses - are presented in the table 2 .

\section{Is there a need for institutional analysis?}

Despite its dominance, the critique of the neoclassical paradigm increases over time. Critiques emphasize that this approach was unable to realistically capture interconnections among society and ecosystems and was unable to analyze the dynamics of environmental property regimes (Bromley, 2004; Vatn, 2005). Furthermore, proposed solutions strongly rely on government decision-making that is far from efficient and is oriented toward the optimal provision of environmental quality (Anderson and Leal, 2001). Methodological and conceptual issues are also raised (see Frey, 2012; Pennington, 2005 or Slavík, 2007 for more evidence). Therefore, the neoclassical paradigm in the economics of the environment is slowly being repressed. In practical decision-making, the cost-benefit analysis is still widely used for the evaluation of particular investment projects (e.g., how to effectively decrease the eutrophication of a water reservoir or how to build an optimal flood protection measure). Through these isolated cases, however, only local problems with direct links to public subsidies can be addressed. Very often, re- 
Table 2. Cost-benefit vs. institutional analysis - overall comparison

\begin{tabular}{ccc}
\hline & Cost-benefit Analysis & Institutional Analysis \\
\hline Institutions viewed as & Neutral & Key variables \\
Human preferences & Static & Subject of continuous change \\
Information & Same & Vary over time \\
& Perfect/Full & Lamong people \\
Transaction costs & & Limited \\
Types of methods & & Significant \\
& Quantitative & Rather qualitative \\
\hline
\end{tabular}

searchers and public representatives deal only with the consequences of environmental degradation without ever addressing the real (and often complex) causes.

The introduction of institutional (often qualitative and sometimes interdisciplinary) research helps to analyze problems that cannot be monetized (or otherwise numerically captured), such as questions regarding the influence of introduced institutional reforms (often coming from the EU) on local environmental protection, the extent of conflicts among key stakeholders that prevent potential damage mitigation caused by natural disasters and the legislative obstacles that cause serious sales problems in secondary material markets during a world crisis. The treatment of these questions is fully relevant for the resolution of the "conservation vs. use conflict". Most often, analyses of these issues center on system performance and on stakeholder or interest group positions rather than on the functioning of an isolated policy tool, which is common in numerous neoclassical studies.

Does this mean, however, that each of the approaches can be more suitable for the solution to a particular environmental problem? ${ }^{1}$ The answer is "not really." Rather, institutional analysis, with its strong focus on real-world aspects, should be considered as a background method for the identification of an environment, its actors and their relationships with respect to all types of environmental problems. Then, if necessary, a cost-benefit approach may be applied for a specific sub-issue, such as the efficient use of public subsidies or the design of economic instruments (fees or taxes). This practice is apparent in the European water policy design as described in this chapter.

The situation within the economics of the environment corresponds to the general debate in economics (as described, e.g., by Jakóbik, 2011 or Sojka, 2009). Mainstream economics should be and, to some extent, has been open to novel ideas, such as concepts of imperfect competition or bounded rationality. As emphasized, e.g., by Frey (2011, p. 21), this evolution of alternatives "does not mean that standard neoclassical economics is superfluous and a waste of effort. Quite the contrary, neoclassics is important as a background theory into which the unorthodox elements can be introduced".

In addition to the theoretical disputes within the field of science, however, policy recommendations and their applications play a key role with respect to environmental protection. As a result, we may see the combination of different tools (from different groups of scientists) rather than competition among the various techniques. A good example of this collaborative result is the EU Water Framework Directive (2000/60/EC), which promotes institutional changes as well as economic tools to improve the quality of European waters. On the one hand, water management should be reorganized according to hydrological (rather than administrative) borders of river basins, which are in perfect harmony with the requirements of spatial fit between institutions 
and ecosystems, as promoted by Young (2002). On the other hand, water services should be priced accordingly, and it should be expected that the polluter (user) pay the principle. This refers directly to the theoretical idea of the internalization of externalities, as proposed by neoclassical environmental economists (e.g., Pearce \& Turner, 1990), whereas the effect of the former measure is necessary for studying the use of the institutional analysis, as the latter tool may be perfectly designed for use with the environmental valuation techniques.

Therefore, methods and techniques grounded in institutional analysis are consistent and useful instruments in socioeconomic research as they cover a large range of practices varying from case study analyses to sophisticated institutional evaluation frameworks. The specific approach within which quantitative and qualitative aspects are combined to study the effect of institutions is represented by laboratory and field experiments (see, Poteete et al., 2010, for more on this subject). Though the promoters of the institutionally oriented research gain increasing respect over time, the potential of these methods has not, as yet, been fully developed. This statement holds true especially in the post-socialist European countries, in which boards of economists tend to consistently ignore the most current evolutions in the field.

\section{Conclusions}

Over the past several decades, the dynamic evolution within the economics of the environment has resulted in numerous competing paradigms offering different views on the causes of environmental degradation and on possible solutions to this degradation. Furthermore, strong criticism of the mainstream paradigm of neoclassical environmental economics has appeared, and novel research techniques accenting qualitative aspects and an interdisciplinary approach have evolved to study environmental issues. Until now, the overview of this evolution, including mutual interactions among different schools of thought, has consisted of a few fragmented publications quoted in introductory parts and has not yet been treated comprehensively. Accordingly, the application of the novel methods grounded in the institutional analysis has been scarce with respect to the Central European scale.

Within the paper, the motivations that drove the continuous shift from the cost-benefit to the institutional analysis in the environmental research were analyzed. From the described aspects of the institutional analysis, there is no doubt that the qualitative techniques and interdisciplinary research show a lower level of formalization. Therefore, the application of these techniques requires proper (unbiased) implementation by individual scientists. A verbal step-be-step explanation of the implementation is of critical importance for others as they attempt to follow the research design, the data analyses and the derived conclusions (including their reliability). The crucial step in the process is linking the research to a particular paradigm of the economic theory. Nevertheless, these aspects do not discredit the use of institutional analysis in comparison with the quantitatively oriented cost-benefit analysis. Using numbers incorrectly, however, may bring similarly false results and promote poor understanding of the description. In a certain context, the combination of different types of methods may be a suitable option to reveal how people act in different institutional, historical and cultural environments.

The goal (and the future challenge) of the theoretical comparative investigation is to foster the dialogue regarding methodological issues between related theoretical approaches. The effort devoted to reconciling the competing paradigms and their methodologies could be honored with the implementation of a more consistent environmental policy in the future.

\section{References}

Anderson, T. L., \& Leal, R. (2001). Free Market Environmentalism. New York, NY: Palgrave.

Anderson, T. L., \& Snyder, P. (1997). Water Markets - Priming the Invisible Pump. Washington, DC: Cato Institute.

Bates, R. H., Greif, A., Levi, M., Rosenthal, J. L., \& Weingast, B. (2000). The Analytical Narrative Project. The American Political Science Review, 94(3), 696-702.

Beder, S. (2011). Environmental economics and ecological economics: the contribution of interdisciplinarity to understanding influence and effectiveness. Environmental Conservation, 38(2), 140-150.

Berkes, F., \& Folke, C. (Eds.). (1998). Linking Social and Ecological Systems: Management Practices and Social Mechanisms for Building Resilience. New York, NY: Cambridge University Press. 
Bromley, D. W. (2004). Reconsidering Environmental Policy: Prescriptive Consequentialism and Volitional Pragmatism. Environmental and Resource Economics, 28(1), 73-99.

Common, M., \& Stagl, S. (2005). Ecological Economics: An Introduction. New York, NY: Cambridge University Press.

Cordato, R. (2004). Toward an Austrian Theory of Environmental Economics. The Quarterly Journal of Austrian Economics, 7(1), 3-16.

Dolan, E. G. (2006). Science, Public Policy and Global Warming: Rethinking the Market-Liberal Position. Cato Journal, 26(3), 445-468.

European Parliament, Council (2000). Water Framework Directive (2000/60/EC). Retrieved from http://ec.europa.eu/environment/water/waterframework/.

Frey, B., \& Stutzer (2008). Environmental morale and motivation. In A. Lewis (Ed.), The Cambridge Handbook of Psychology and Economic Behaviour (pp. 406-428). Cambridge, UK: Cambridge University Press.

Frey, B. (2011). A Plea for Unconventional Economics. In L. Sacconi, G. D. Antoni (Eds.), Social Capital, Corporate Social Responsibility, Economic Behaviour and Performance (pp. 21-41). New York, NY: Palgrave Macmillan.

Frey, B., \& Steiner, L. (2012). Political Economy: Success or Failure? Contemporary Economics, 6(3), $10-21$.

Furubotn, E. G., \& Richter, R. (2005). Institutions and Economic Theory ( $2^{\text {nd }}$ ed.). Ann Arbor, MI: University of Michigan Press.

Germani, A. R. (2004). Environmental Law and Economics in U. S. And E. U.: A Common Ground? (Discussion Paper No 45) Centre for Financial and Management Studies. Retrieved from http:// www.cefims.ac.uk/documents/research-34.pdf.

Hendl, J. (2005). Kvalitativní výzkum: základní metody a aplikace [Qualitative research: methods and aplications]. Praha: Portál.

Hoel, M. (Ed.). (2004). Recent Developments in Environmental Economics (Vol. 1). Cheltenham, UK: Edward Elgar Publishing.

Huutoniemi, K., Klein, J. T., Bruun, H., \& Kukkinen, J. (2010). Analyzing interdisciplinarity: Typology and indicators. Research Policy, 39(1), 79-88.
Jakóbik, W. (2011). Theory of Economy as the Original Cause of the World Crisis. Contemporary Economics, 5(2), 4-15.

Jílková, J., Holländer, R., Kochmann, L., Slavik, J., \& Slavíková, L. (2010). Economic Valuation of Environmental Resources and its Use in Local Policy Decision-Making: A Comparative Czech-German Border Study. Journal of Comparative Policy Analysis: Research and Practice, 12(3), 299-309.

Jilkova, J., \& Slavikova, L. (2009). Ekonomie životního prostředí na rozcestí [Economics of the Environmental Protection at the Crossroad]. Politická ekonomie, 57(5), 660-676.

Kornai, J. (2008). Obory společenských věd: Odluka nebo spolupráce? [Disciplines of social sciences: separation or cooperation?] Politická ekonomie, 56(1), 5-16.

Kula, E. (1998). History of Environmental Economic Thought. London, UK: Routledge.

North, D. C. (2005). Understanding the Process of Economic Change. Princeton, UK: Princeton University Press.

Oates, W. E. (Ed.). (1994). The Economics of the Environment. Cheltenham, UK: Edward Elgar Publishing.

Ostrom, E., Burger, J., Field, C. B., Norgaard, R. B., \& Policansky, D. (1999). Revisiting the Commons. Local Lessons, Global Challenges. Science, 284(5412), 278 - 282.

Ostrom, E. (2005). Understanding Institutional Diversity. Princeton, UK: Princeton University Press.

Ostrom, E. (2006). Governing the Commons: The Evolution of Institutions for Collective Action. New York, NY: The Cambridge University Press.

Ostrom, E. (2008). Institutions and the Environment. Economic Affairs, 28(3), 24-31.

Paavola, J. (2007). Institutions and environmental governance: A reconceptualization. Ecological Economics, 63(1), 93 - 103.

Pearce, D. W., \& Turner, R. K. (1990). Economics of Natural Resources and the Environment. Baltimore, MD: The John Hopkins University Press.

Poteete, A. R., Janssen, M. A., \& Ostrom, E. (2010). Working Together: Collective Action, the Commons, and Multiple Methods in Practice. Princeton, NJ: Princeton University Press.

Pennington, M. (2005). Liberty, Markets, and Environmental Values: A Hayekian Defense of Free-Market Environmentalism. The Independent Review, 10(1), 39-57. 
Siegers, J. J. (1992). Interdiciplinary Economics. De Economists 140(4), 531-547.

Sima, J. (2004). Ekonomie a právo [Law and Economics]. Praha: Nakladatelství Oeconomica.

Slavik, J. (2007). Neoklasická ekonomie a ochrana životního prostředí [Neoclassical economy in environmental protection]. Politická ekonomie, 55(4), 526-538.

Slavikova, L., Kluvankova-Oravska, T., \& Jilkova, J. (2010). Bridging theories on environmental governance: Insights from free-market approaches and institutional ecological economics perspectives. Ecological Economics, 69(7), 1368-1372.

Sojka, M. (2009). Stane se institucionální ekonomie paradigmatem 21. století? [Will the institutional economy become the 21st century paradigm?] Politická ekonomie, 57(3), 297-304.

Stroup, R. L. (2000). Free Riders and Collective Action Revisited. The Independent Review, 4(4), 485-500.

Vatn, A. (2005). Institutions and the Environment. Cheltenham, UK: Edward Elgar Publishing.

Veblen, T. B. (1899). The theory of the Leisure Class: An economic Study of the Evolution of Institutions. New York, NY: MacMillan.

Williamson, O. E. (1981). The Economics of Organization: The Transaction Cost Approach. The American Journal of Sociology, 87(3), 548-577.

Young, O. R. (2002). The Institutional Dimensions of Environmental Change: Fit, Interplay and Scale. Cambridge, MA: The MIT Press.

\section{Endnotes}

1 We thank the anonymous reviewer of the paper for this question.

\section{Acknowledgements:}

The paper was written with the institutional support of Faculty of Economics (University of Economics in Prague) and the grant No. F5/3/2012. 